\title{
Analisis Pengelolaan Aset Desa di Kota Kotamobagu
}

\section{RESTI WISNA POBELA ${ }^{1}$, HERMAN KARAMOY ${ }^{2}$, LINDA LAMBEY ${ }^{3}$}

\author{
${ }^{1,2,3}$ Program Magister Akuntansi, Fakultas Ekonomi dan Bisnis Universitas Sam Ratulangi \\ email:restishilla81@gmail.com ${ }^{1}$, hermankaramoy@yahoo.com ${ }^{2}$, lindalambey@yahoo.com ${ }^{3}$
}

\begin{abstract}
The study aims to analyze the process of planning, procurement, administration, reporting and supervision of village assets in Kotamobagu City, the inhibiting factors and efforts taken to solve the problems. This is a qualitative study with case study approach. The government of Kotamobagu city and four villages in three sub-districts are respondents of this study. Data were obtained through in-depth interviews, observation and documentation study. The results show that the process of planning, procurement, administration, reporting and monitoring of village assets in Kotamobagu city have not been well implemented, where the regulation as the reference for the village assets management has not been implemented. In addition, the Village Government has not completely listed their assets to compile with the mandate of Village Act. The obstacles are also in human resources competency, communications, legal certainty, executor attitude, organizational skills expertise, transparency and organizational commitment. On the other hand, efforts taken to solve the problems are to develop self-competence of human resources by sufficient learning, obey the regulation in managing public assets, provide public service in form of systematic registration program, development of village financial system application and the establishment of village-owned enterprise. Recommendations are to focus more on improving the human resources competence, conduct socialization, technical guidance and continuous education training, list the asset inventory imminently, and socialize as well as implement the regulation.
\end{abstract}

\section{Keywords: Village Asset Management, Human Resources, Communications, Regulation and Organizational} Commitment.

\begin{abstract}
Abstrak. Tujuan penelitian ini adalah untuk menganalisis proses perencanaan, pengadaan, penatausahaan, pelaporan dan pengawasan aset desa di Kota Kotamobagu, faktor-faktor yang menjadi penghambat dan upayaupaya yang dilakukan. Ini adalah penelitian kualitatif dengan pendekatan studi kasus. Pemerintah Kota Kotamobagu dan empat desa yang ada di tiga Kecamatan adalah objek penelitian ini. Data diperoleh melalui teknik wawancara mendalam, pengamatan dan studi dokumentasi. Hasil penelitian menunjukkan bahwa proses perencanaan, pengadaan, penatausahaan, pelaporan dan pengawasan aset desa di Kota Kotamobagu belum dilaksanakan dengan baik, dimana regulasi yang menjadi acuan pengelolaan aset desa belum diterapkan. Selain itu amanat Undang-Undang Desa yaitu menginventarisir semua aset desa belum sepenuhnya dilakukan oleh pemerintah desa. Adapun kendala yang dihadapi adalah kompetensi sdm, komunikasi, kepastian hukum, sikap pelaksana, keahlian pengelola kegiatan, transparansi dan komitmen organisasi. Upaya yang dilakukan yaitu dengan mengembangkan sendiri kompetensi SDM melalui banyak belajar, mengikuti regulasi pengelolaan barang milik daerah, pelayanan publik berupa program pendaftaran teknik sistematis, pengembangan aplikasi sistem keuangan desa dan pembentukan badan usaha milik desa. Saran yang dapat diberikan yaitu lebih fokus pada peningkatan kompetensi sdm melalui sosialisasi, bimbingan teknis dan pendidikan pelatihan yang berkesinambungan, segera melakukan inventarisasi aset, dan mensosialisasikan sekaligus menerapkan regulasi yang berlaku.
\end{abstract}

Kata Kunci : Pengelolaan Aset Desa, Sumber Daya Manusia, Komunikasi, Regulasi dan Komitmen Organisasi.

\section{Pendahuluan}

Dengan disahkannya Undang-Undang No. 6 Tahun 2014 tentang desa, diharapkan segala kepentingan dan kebutuhan masyarakat desa dapat diakomodir dengan lebih baik. Pemberian kesempatan yang lebih besar bagi desa untuk mengurus tata pemerintahannya sendiri serta pemerataan pelaksanaan pembangunan diharapkan dapat meningkatkan kesejahteraan dan kualitas hidup masyarakat desa, sehingga permasalahan seperti kesenjangan antar wilayah, kemiskinan dan masalah sosial budaya lainnya dapat diminimalisir (BPKP, 2015). Pembangunan di desa pada era kepemimpinan Presiden Joko Widodo menjadi salah satu agenda pembangunan nasional yang tertuang dalam nawa cita yakni "Membangun Indonesia dari pinggiran dengan memperkuat daerah-daerah dan desa dalam kerangka NKRI" sebagaimana tertuang dalam Peraturan Presiden No. 2 Tahun 2015 tentang RPJMN 2015-2019. Undang-Undang No. 6 Tahun 2014 tentang desa, janji pemerintah "1 Desa 1 Milyar" mungkin akan jadi kenyataan (Lestyowati, 2015).

Namun dari berita bagus ini, muncul permasalahan karena komunikasi dalam bentuk sosialisasi terkait regulasi pengelolaan aset desa belum diterapkan sehingga belum sepenuhnya dipahami oleh para 
pelaksana di daerah khususnya pemerintah desa. Hal lain yang cukup menjadi perhatian adalah semakin besarnya dana yang dikucurkan pemerintah pusat ke desa semakin besar, selain itu sebagian dari angka tersebut pasti digunakan untuk pengadaan barang/jasa yang dibutuhkan desa. Tahun 2016 pemerintah pusat telah mengucurkan dana desa sebesar Rp. 46,98 trilyun dan Kota Kotamobagu sendiri sudah menerima dana sebesar Rp.10.241.910,-. Besarnya dana yang harus dikelola oleh pemerintah desa belum selaras dengan kemampuan SDM di desa yang beragam, diperlukan perencanaan yang matang.

Dana Desa (DD) dari APBN dan Alokasi Dana Desa (ADD) dari APBD Kabupaten/Kota yang dikelola dalam APBDes merupakan modal yang digunakan untuk mengelola aset tersebut yang bertujuan untuk kesejahteraan bersama, oleh karena itu pengelolaannya harus dengan sebaik-baiknya. Pengelolaan aset desa perlu memiliki sistem manajemen yang efektif dan handal sebagai alat untuk melakukan perencanaan, pengadaan, penatausahaan, pelaporan dan sistem pengawasannya. Perencanaan dan pengawasan yang berkesinambungan diperlukan untuk menghindari penyimpangan dari peraturan yang berlaku dalam setiap tahapan pengelolaan barang milik desa dan mengarahkan agar pekerjaan yang dilaksanakan berjalan sesuai dengan rencana yang telah ditetapkan. Kesemuanya ini tidak terlepas dari orang-orang yang berkompeten dalam bidangnya.

Pengelolaan aset daerah memiliki tahapan-tahapan dalam pelaksanaannya. Salah satu tahapan tata kelola aset yang baik adalah penginventarisasian aset. Mengingat pentingnya manajemen aset bagi pemerintah desa, maka sudah menjadi keharusan bagi pemerintah desa untuk melakukan pengelolaan aset desa secara profesional, efektif dan mengedepankan aspek - aspek ekonomis agar biaya - biaya yang dikeluarkan tepat sasaran, tepat penggunaan, tepat penerapan dan tepat sesuai dengan peraturan perundang-undangan yang berlaku. Menurut Sumini (2010:13), sebagian besar fisik barang tidak bisa langsung diidentifikasi karena tidak diberi nomor register barang atau nomor register yang menempel pada fisiknya. Nomor register merupakan bagian dari kodefikasi aset daerah yang memuat nomor urut pencatatan dari setiap barang, pencatatan terhadap barang yang sejenis, tahun pengadaan yang sama dan besaran harga.

Seperti juga hasil penelitian Risnawati (2017) adanya pembelian barang yang tidak tercatat dalam buku inventaris, tidak diketahui asal usul barang apakah dari hasil jual beli atau hibah, rendahnya kinerja pengurus dan pembantu pengurus barang, tidak adanya aturan yang mengikat (jelas dan legal) terhadap pentingnya pengelolaan aset seperti petunjuk pelaksanaan dan petunjuk teknis proses pencatatan dan pelaporan aset yang sah, pemahaman petugas pengelola aset masih minim. Fenomena lainnya seperti yang terjadi di Kabupaten Wonogiri, banyak yang sindung riwut (kacau), bermasalah, menjadi obyek sengketa, tidak jelas keabsahan pemilikannya, tak teradministrasikan secara baik. Hal itu terungkap dalam Rapat Panitia Khusus (Pansus) pembahasan Rancangan Peraturan Daerah (Ranperda) tentang pengelolaan aset desa (Harian Suara Merdeka, 2017).

Carut marut pengelolaan barang milik negara/daerah yang sudah diuraikan, terjadi juga pada pengelolaan aset desa di Kota Kotamobagu. Mengingat pengelolaan aset desa cakupannya luas maka dalam penelitian ini difokuskan pada proses perencanaan, pengadaan, penatausahaan, pelaporan dan pengawasan. Perencanaan adalah tahapan kegiatan secara sistematis untuk merumuskan berbagai rincian kebutuhan barang milik desa. Pengadaan adalah kegiatan untuk melakukan pemenuhan kebutuhan barang dalam rangka penyelenggaraan pemerintahan desa. Sedangkan Penatausahaan adalah rangkaian kegiatan yang di lakukan meliputi pembukuan, inventarisasi dan pelaporan aset desa sesuai dengan ketentuan yang berlaku. Selanjutnya pelaporan merupakan salah satu bentuk pengamanan aset desa secara administrasi dan yang terakhir adalah pengawasan. (Permendagri No 01 Tahun 2016).

Fenomena pengelolaan aset desa di Kota Kotamobagu, masih kurangnya pemahaman pemerintah desa dan TPK terhadap proses pengadaan, kesemuanya tidak terlepas dari proses perencanaan yang matang, selain itu belum mematuhi peraturan perundang-undangan yang berlaku. Mengingat proses pengadaan sangat rawan, jangan sampai akibat dari ketidaktahuan dapat menjadi bumerang bagi para pihak yang terlibat dalam pengadaan. Hal ini menjadi ketertarikan bagi penulis untuk meneliti pengelolaan aset desa karena pengadaan barang/jasa kebutuhan desa menggunakan APBDes yang sumbernya dari dana desa maupun ADD dengan kata lain aset desa seiring sejalan dengan dana desa, tidak bisa dipisahkan.

Setiap ada musrembang desa semua lembaga masyarakat diundang dan semua bebas menyampaikan aspirasinya khusus untuk kegiatan pengadaan kebutuhan desa, semua aparat desa mengusulkan dengan anggaran yang ada beli ini-beli itu entah hal tersebut dibutuhkan desa atau tidak, ini menjadi tanda tanya apakah kepala desa selaku pengguna barang memperhatikan hal tersebut. Selanjutnya dalam hal penatausahaan aset desa banyak aset vital seperti kantor desa, sekolah dan lainlain tidak memiliki bukti kepemilikan atas nama desa, hal ini penting diteliti karena aset vital tersebut 
adalah jantung desa dimana keseharian kegiatan pemerintahan berlangsung disitu. Terkait masalah pelaporan, sering BPD dan aparat desa kurang sepaham dimana pelaporan yang diberikan belum sesuai dengan aturan. Demikian pula karena kurangnya pengawasan setiap pergantian kepala desa banyak aset desa baik bergerak maupun tidak bergerak penyerahannya sering menjadi masalah, selain itu banyak aset desa yang berpotensi menambah PADes belum dikelola dengan baik.

Dan yang membuat penulis tertarik mengangkat isu aset desa karena selain tidak seheboh dana desa sepertinya masalah aset desa kurang mendapat perhatian pemerintah. Dari uraian diatas dan melihat fenomena kasus yang sedang terjadi berdasarkan evaluasi dari instansi terkait kasus tersebut dianggap sebagai temuan dimana penggunaan dana desa khususnya pengadaan kebutuhan desa terdapat penyimpangan dari kewajaran. Pembatasan fokus dalam penelitian ini karena aset desa masih dalam jumlah kecil dibanding aset pemerintah daerah dan kelima proses yang sudah diuraikan dominan terjadi didesa yaitu bagaimana perencanaan pengadaan kebutuhan desa, penatausahaan dan pelaporannya seperti apa, yang terakhir proses pengawasan.

Tujuan penelitian ini untuk : 1) menganalisis proses perencanaan, pengadaan, penatausahaan, pelaporan dan pengawasan aset desa di Kota Kotamobagu 2) menganalisis faktor-faktor penghambat 3) menganalisis upaya apa saja yang dilakukan untuk pengelolaan aset desa lebih baik.

\section{Kerangka Konseptual}

Kerangka konsep merupakan gambaran atau bangunan utuh suatu penelitian dan merupakan perpaduan dari berbagai aspek yang dimulai dari permasalahan, aspek-aspek terkait yang hendak diteliti hingga kemungkinan-kemungkinan lain yang ingin dihasilkan dari keseluruhan proses penelitian. Dengan latar belakang masalah, rumusan permasalahan dikaitkan dengan teori yang ada maka kerangka konseptual dalam penelitian ini adalah sebagai berikut :

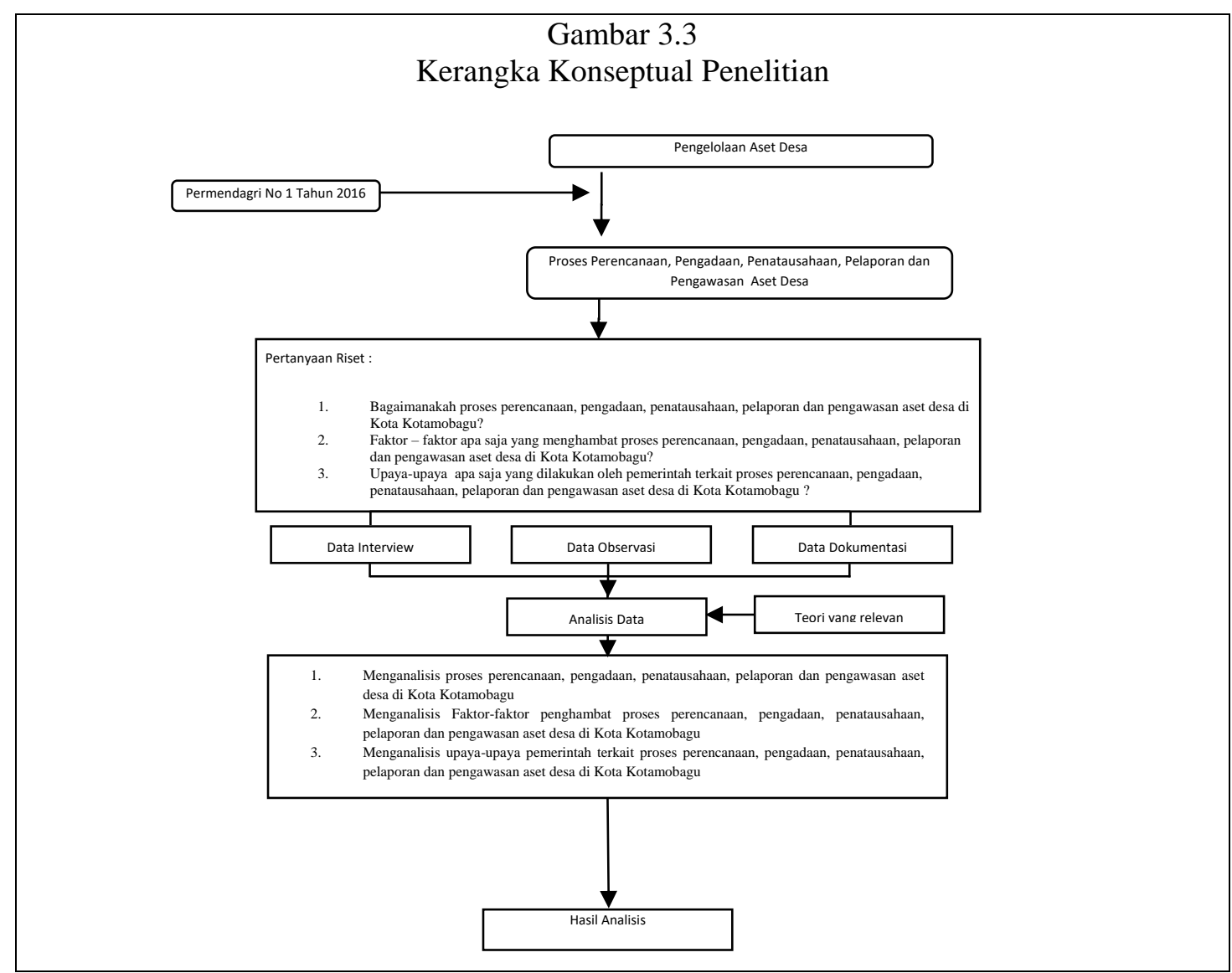

\section{Metode Penelitian}

Penelitian ini menggunakan metode kualitatif dengan pendekatan studi kasus (case study) yang menelaah sebuah "kasus" tertentu dalam konteks atau setting kehidupan nyata kontemporer. Menurut Endraswara (2012:78), studi kasus dapat dibagi menjadi dua golongan. Dalam Penelitian ini menggunakan studi kasus berupa penyimpangan dari kewajaran. Studi kasus ini bersifat kuratif dan disebut studi kasus retrospektif (retrospective case study) yang memungkinkan ada tindak lanjut 
perbaikan dari suatu kasus (treatment). Tindak lanjut perbaikan tidak harus dilakukan oleh peneliti, tetapi oleh orang lain yang berkompeten, peneliti hanya memberikan masukan dari hasil penelitian. Satori dan Komariah (2014:202) menjelaskan penelitian kualitatif adalah penelitian yang menekankan pada quality atau hal yang terpenting dari sifat suatu barang/jasa.

Teknik pengumpulan data yang dilakukan dalam penelitian ini adalah wawancara, studi dokumentasi dan observasi atau gabungan ketiganya disebut triangulasi. Penentuan infoman dalam penelitian ini dilakukan dengan tehnik purposive sampling yaitu menetapkan kriteria tertentu yang harus dipenuhi oleh informan yang akan dijadikan sumber informasi. Metode analisis data yang digunakan dalam penelitian ini adalah analisis model Milles dan Huberman. Aktivitas analisis data Miles and Huberman dalam Sugiyono (2015:404), terdiri atas: data reduction, data display dan conclusion drawing/verification yang dilakukan secara interaktif dan berlangsung secara terus menerus sampai tuntas, sehingga datanya mencapai jenuh. Uji keabsahan data dalam penelitian ini menggunakan uji credibility yang terdiri dari triangulasi sumber dan triangulasi teknik. Uji dependability dilakukan oleh dosen pembimbing untuk memeriksa transkrip hasil wawancara, bagaimana melakukan analisa data, melakukan keabsahan data penelitian sampai membuat kesimpulan.

\section{Analisis dan Pembahasan}

Penelitian ini dilakukan selama 3 (tiga) bulan sejak bulan Juli sampai September 2017 dengan melakukan wawancara sesuai dengan pedoman wawancara kepada informan dengan menggunakan alat perekam untuk merekam isi wawancara serta menggunakan instrumen pendukung lainnya berupa buku catatan, kamera untuk mendokumentasikan kegiatan di lapangan dan laptop untuk mengetik hasil penelitian dan rekaman wawancara sehingga terbentuk transkrip.

\section{Proses Pengelolaan Aset Desa (Perencanaan, Pengadaan, Penatausahaan, Pelaporan dan Pengawasan)}

Pedoman pengelolaan aset yang digunakan oleh pemerintah desa di Kota Kotamobagu masih menggunakan pedoman pengelolaan barang milik daerah hal ini disebabkan belum diterapkannya Peraturan Menteri Dalam Negeri No. 01 Tahun 2016 tentang pengelolaan aset desa.

1. Proses perencanaan, pada dasarnya perencanaan kebutuhan aset desa dalam bentuk kegiatan fisik sudah sesuai dengan regulasi yang diawali dengan musrembang desa melibatkan seluruh komponen yang ada didesa akan tetapi dalam perencanaan kebutuhan operasional kantor belum sesuai regulasi yang seharusnya ada kepala urusan yang bertanggung jawab mengurus aset desa.

2. Proses pengadaan barang/jasa di desa dilaksanakan oleh TPK dan dilakukan secara swakelola, yang diawali tahap persiapan dimulai dari survey lokasi, survey toko sampai pada penentuan tenaga kerja akan tetapi karena masih kurangnya sosialisasi dan belum diterapkannya regulasi pengelolaan aset desa sehingga TPK maupun pengurus aset belum mempunyai aturan yang menjadi landasan selain itu kompetensi SDM dalam hal ini pelaksana kegiatan masih kurang dikarenakan juga belum pernah mendapatkan pelatihan.

3. Proses penatausahaan aset desa masih dilakukan seadanya dimana kegiatan fisik sering lupa dicatat selain itu pemberian kode, labeling belum sesuai ketentuan dan yang menjadi kendala selanjutnya pemerintah desa belum melaksanakan amanat Undang-Undang Desa yaitu inventarisasi aset hal ini disebabkan hampir semua aset desa belum memiliki kepastian hukum kepemilikan aset.

4. Proses pelaporan aset desa sudah sesuai ketentuan yaitu dilaksanakan setahun atau lima tahun sekali dan biasanya pada saat pergantian kepala desa, pelaporan dilakukan oleh sekretaris desa dalam bentuk laporan pertanggung jawaban kepala desa. Bentuk laporan yang disampaikan yaitu secara tertulis kepada Walikota dalam bentuk LPPD dan ke BPD berupa LKPJ akan tetapi asas transparansi belum sepenuhnya dilakukan oleh pemerintah desa dimana BPD sebagai lembaga yang ada didesa hanya mendapatkan laporan lisan yaitu pada saat mendengarkan penyampaian LKPJ.

5. Proses Pengawasan aset desa di Kota Kotamobagu belum berjalan dengan baik dimana Inspektorat selaku pihak yang melakukan pengawasan menggunakan aturan yang tidak sesuai, selain itu banyak aset desa yang berpotensi menambah PADes karena kurangnya komitmen dari pemerintah desa sehingga belum memberikan kontribusi kedesa. 


\section{Faktor - Faktor Yang Menjadi Penghambat}

Terdapat 7 (tujuh) faktor yang menjadi penghambat pengelolaan aset desa di Kota Kotamobagu yaitu 1) kompetensi SDM yang masih kurang baik dari pengurus aset maupun tim pengelola kegiatan (TPK); 2) kurangnya komunikasi tentang penerapan regulasi pengelolaan aset desa; 3) kepastian hukum kepemilikan aset; 4) sikap pelaksana yang belum patuh pada aturan; 5) keahlian pengelola kegiatan dalam menyikapi keadaan pasar yang berubah-ubah; 6) kurangnya transparansi pemerintah desa terkait pelaporan; 7) komitmen organisasi belum berjalan dengan maksimal.

1. Kompetensi SDM menjadi faktor penghambat dalam proses pengadaan dan penatausahaan aset desa dimana pemahaman dan pelatihan yang masih kurang sehingga baik pengurus aset desa maupun tim pelaksana kegiatan belum sepenuhnya memahami tugas pokok walaupun latar belakang pendidikan sarjana tapi bukan jurusan sehingga menemui kesulitan dan kewalahan dalam pelaksanaan tugasnya. Selain itu pada proses pengawasan yang dilakukan Inspektorat, pemerintah desa dalam pembelanjaan sudah sesuai dengan aturan tidak ada belanja fiktif akan tetapi pengadministrasiannya masih kurang tertib apalagi setelah ada sistem siskeudes mereka lebih berfokus ke sistem sementara nota pembelanjaan tidak rapi.

Menurut Notoatmodjo ((2009:16), pelatihan merupakan upaya yang berkaitan dengan peningkatan kemampuan atau ketrampilan karyawan yang sudah menduduki suatu pekerjaan atau tugas tertentu. Penekanan dalam suatu pelatihan adalah tugas yang akan dilaksanakan (job orientation), disamping itu pelatihan pada umumnya menekankan kemampuan psikomotor meskipun didasari pengetahuan dan sikap, metode belajar mengajar yang digunakan pada pelatihan lebih inovatif dibandingkan dengan pendidikan.

Perlu adanya pelatihan secara berkesinambungan untuk menunjang pelaksanaan tugas dan tertibnya pengadministrasian aset desa, seperti yang dikemukakan oleh Martoyo (2000:14-15) untuk menyediakan dan mempertahankan jumlah dan kualitas sumber daya manusia (tenaga kerja) yang tepat bagi organisasi agar tujuan manajemen tercapai dengan baik dan tepat salah satunya dengan pendidikan dan pelatihan (education and trainning). Kompetensi SDM sangat penting untuk implementasi dari setiap kebijakan, SDM yang kurang memadai berdampak pada proses pengelolaan aset desa tidak berjalan dengan efektif.

2. Komunikasi menjadi faktor penghambat pada proses pengadaan dan pengawasan dimana pemerintah Kota Kotamobagu dan pemerintah desa belum melakukan komunikasi lewat sosialisasi tentang penerapan regulasi pengelolaan aset desa sehingga pihak pengelola aset desa dalam melaksanakan tugasnya masih meraba-raba regulasi yang menjadi acuan. Tidak adanya komunikasi yang baik dalam sebuah kebijakan, maka akan membuat kualitas kebijakan menjadi tidak efektif. Komunikasi diperlukan untuk menyebarkan informasi penting terkait pelaksanaan kebijakan yang menyangkut pengelolaan aset desa. Dalam penerapan kebijakan membutuhkan kerjasama semua pihak, apalagi jika implementor bingung dengan apa yang akan dilakukan disebabkan ketidakjelasan informasi.

Menurut Edward (1980) salah satu variabel dalam suatu organisasi yang mempengaruhi implementasi kebijakan yaitu komunikasi (communications). Sumber informasi yang berbeda dapat melahirkan interpretasi yang berbeda pula. Agar implementasi berjalan efektif, siapa yang bertanggung jawab melaksanakan sebuah keputusan harus mengetahui apakah mereka dapat melakukannya. Implementasi akan berjalan efektif apabila ukuran-ukuran dan tujuan-tujuan kebijakan dipahami oleh individu-individu yang bertanggung jawab dalam pencapaian tujuan kebijakan. Kejelasan ukuran dan tujuan kebijakan perlu dikomunikasikan sehingga implementor mengetahui secara tepat ukuran maupun tujuan kebijakan tersebut.

3. Kepastian hukum menjadi faktor penghambat dalam proses penatausahaan. Banyak aset desa belum memiliki kepastian hukum kepemilikan aset dan hal ini juga menjadi kendala dalam penginventarisasian aset desa. Sangat penting untuk segera melegalkan semua aset desa (tanah dan bangunan) apalagi yang berasal dari hibah karena sudah banyak kejadian mana yang dulunya orang tua hibahkan dan tidak memiliki bukti kepemilikan atas nama desa dikemudian hari bisa menimbulkan masalah dan bila memungkinkan diambil oleh keturunannya.

Dalam Undang-Undang Desa No 6 Tahun 2014 pasal 76 menyatakan sebagai berikut (ayat 4) kekayaan milik desa yang berupa tanah disertifikatkan atas nama pemerintah desa; (ayat 6) bangunan milik desa harus dilengkapi dengan bukti status kepemilikan dan ditatausahakan dengan tertib. Menurut Salim H.S (2001:99), Bezit adalah suatu keadaan yang senyatanya seseorang menguasai suatu benda, baik benda bergerak maupun tidak bergerak namun secara yuridis formal benda itu belum tentu miliknya. Ini berarti bahwa bezitter hanya menguasai benda secara materiil 
saja sedangkan secara yuridis formal benda itu milik orang lain. Penting bagi desa untuk menginventarisir seluruh asetnya agar bisa diketahui mana yang sudah dan belum memiliki sertifikat.

4. Sikap pelaksana menjadi faktor penghambat pada proses perencanaan dan pengawasan. Salah satu tugas dari kepala desa adalah menetapkan pengurus aset desa hal ini sejalan dengan arahan yang disampaikan pihak Inspektorat untuk membentuk pengurus barang dengan tujuan agar apa yang direncanakan disusun oleh yang bersangkutan dan sesuai dengan kebutuhan desa, sehingga nantinya ketika barang tersebut sudah ada, tidak terbengkalai pengadministrasiannya. Selain itu peralihan pimpinan ada-ada saja yang terjadi dan kebanyakan mana aset yang diperoleh semasa jabatannya tidak ada yang tertinggal dikantor atau diserahkan tapi tidak semua, ini menggambarkan sikap pelaksana yang belum patuh terhadap aturan dan hal ini berpengaruh dalam implementasi kebijakan pengelolaan aset desa.

Edward III (1980) menjelaskan bahwa salah satu faktor penting dalam studi implementasi kebijakan adalah sikap pelaksana, jika implementasi kebijakan diharapkan dapat efektif, maka para pelaksana kebijakan tidak hanya sebatas mengetahui apa yang harus dilakukan, akan tetapi harus memiliki dorongan keinginan untuk melakukan tugas tersebut. Perilaku pelaksana yang kurang berpartisipasi aktif dapat menghambat efektivitas implementasi kebijakan.

5. Keahlian pengelola kegiatan menjadi salah satu faktor penghambat dalam proses pengadaan. Pada dasarnya TPK sudah melaksanakan salah satu tugasnya sesuai dengan ketentuan yaitu melakukan survey harga dibeberapa toko akan tetapi karena keadaan pasar yang berubah-ubah maka apa yang sudah dianggarkan tidak sesuai dengan dilapangan, dengan situasi seperti ini dituntut keahlian pengelola kegiatan bagaimana menyikapi hal tersebut. Menurut Griffin (2004), keahlian manajer dibedakan menjadi keahlian teknis, interpersonal, konseptual, diagnostik, komunikasi, pengambilan keputusan dan manajemen waktu. Peran seorang manajer dalam hal ini TPK dengan keahlian diagnostik yaitu kemampuan manajer untuk memvisualisasikan jawaban yang paling sesuai dengan situasi tertentu dengan kata lain seorang manajer dapat mendiagnosa atau menganalisis masalah yang terjadi.

6. Transparansi menjadi faktor penghambat pada proses pelaporan dimana pelaporan dimaksud dalam bentuk lisan saat mendengarkan penyampaian LKPJ kepala desa dan yang dibahas secara keseluruhan mulai dari pembangunan, pengadaan tapi tidak terperinci. Seharusnya LKPJ tersebut diperbanyak dan dibagikan ke semua yang hadir terlebih ke BPD yang tujuannya agar dapat dilihat mana yang sudah dibuat maupun dibeli, mana yang menjadi prioritas kebutuhan desa sekaligus mengecek keberadaan aset apakah sudah teradministrasi dengan baik. Memang secara lisan diketahui ada pengadaan tapi karena kesibukan bisa saja sekarang diketahui besok tidak diingat lagi, alangkah baiknya harus ada secara tertulis juga.

Menurut Lalolo (2003:13), transparansi adalah prinsip yang menjamin akses atau kebebasan bagi setiap orang untuk memperoleh informasi tentang penyelenggaraan pemerintahan yakni informasi tentang kebijakan, proses pembuatan serta hasil yang dicapai. Mardiasmo (2006:45) transparansi adalah keterbukaan pemerintah dalam memberikan informasi yang terkait dengan aktifitas pengelolaan sumber daya publik kepada pihak yang membutuhkan yaitu masyarakat. Lebih lanjut Mardiasmo menyebutkan tujuan transparansi dalam penyelenggaraan pemerintahan desa yaitu : 1) salah satu wujud pertanggung jawaban pemerintah kepada masyarakat; 2) upaya peningkatan manajemen pengelolaan pemerintahan; 3) upaya peningkatan manajemen pengelolaan dan penyelenggaraan pemerintahan yang baik dan mengurangi kesempatan praktek KKN.

7. Komitmen organisasi merupakan salah satu faktor penghambat pada proses pengawasan. Banyak aset desa yang berpotensi menambah PADes tetapi karena kurangnya komitmen dari pengurus mengakibatkan pengelolaannya tidak maksimal. Ketidakmaksimalan tersebut diantaranya pengaruh pergantian pimpinan, tidak ada ketegasan untuk mengambil aset desa yang tadinya dikelola kelompok tapi tidak pernah memberikan kontribusi ke desa, selain itu karena dari awal proses perencanaan tidak ditetapkan pengurus yang bertanggung jawab mengelola aset desa mengakibatkan aset desa yang sudah diadakan hanya dibiarkan dibalai desa dan parahnya lagi banyak aset yang tidak diketahui lagi keberadaannya.

Zurnali (2010) dengan mengacu pada pendapat-pendapat Meyer and Allen mendefinisikan masing-masing komponen komitmen organisasional sebagai berikut : 1) affective commitment atau komitmen afektif yaitu perasaan cinta pada organisasi atau perusahaan yang memunculkan kemauan untuk tetap tinggal dan membina hubungan sosial serta menghargai nilai hubungan 
dengan organisasi dikarenakan telah menjadi anggota organisasi; 2) continuance commitment atau komitmen berkelanjutan yaitu perasaan berat untuk meninggalkan organisasi dikarenakan kebutuhan untuk bertahan dengan pertimbangan biaya apabila meninggalkan organisasi dan penghargaan yang berkenaan dengan partisipasi didalam organisasi; 3) normative commitment atau komitmen normatif yaitu perasaan yang mengharuskan untuk bertahan dalam organisasi dikarenakan kewajiban dan tanggung jawab terhadap organisasi yang didasari atas pertimbangan norma, nilai dan keyakinan karyawan.

\section{Upaya - Upaya Yang dilakukan}

1. Dengan berbekal pengelola kegiatan sudah memiliki pengalaman mengelola keuangan sehingga dengan adanya program dana desa yang harus dilaksanakan secara swakelola sedikit terbantu. Upaya lain yang dilakukan untuk mengatasi faktor - faktor penghambat dalam proses pengadaan diantaranya pengelola kegiatan mau tidak mau harus mengembangkan sendiri kompetensinya dengan banyak belajar, ini menunjukkan keinginan yang besar dalam menyukseskan program pemerintah. Terkait temuan dari Inspektorat tentang administrasi yang belum baik maka upaya yang dilakukan dengan mengirim perbaikan selain itu pengadministrasian SPJ disusun secara rapi per tanggal dan di gandakan untuk keperluan bagian Keuangan dan Inspektorat. Upaya lain yang dilakukan pihak Inspektorat berupa arahan dan pembinaan berulang kali ke pemerintah desa untuk jangan terlalu fokus di aplikasi siskeudes, kembali kemanual dulu dengan menyusun rapi setiap SPJ kemudian menginputnya disistem.

Konstruktivisme adalah salah satu filsafat pengetahuan yang menekankan bahwa pengetahuan adalah bentukan (konstruksi) kita sendiri. Menurut Wheatley (1991), teori konstruktivisme adalah sebuah teori yang memberikan kebebasan terhadap manusia yang ingin belajar atau mencari kebutuhannya dengan kemampuan untuk menemukan keinginan tersebut dengan bantuan fasilitasi orang lain. Dua prinsip utama dalam pembelajaran dengan teori belajar konstruktivisme, 1) pengetahuan tidak dapat diperoleh secara pasif tetapi secara aktif oleh struktur kognitif siswa; 2) fungsi kognitif bersifat adaftif dan membantu pengorganisasian melalui pengalaman nyata yang dimiliki siswa. Teori belajar konstruktivisme menunjukkan bahwa kompetensi dari seseorang tidak didapat secara pasif melainkan secara aktif seperti yang dilakukan oleh pengelola kegiatan dikarenakan belum pernah mendapatkan pelatihan maka untuk memudahkan pelaksanaan tugasnya pengelola kegiatan pro aktif belajar sendiri secara otodidak.

2. Karena belum adanya komunikasi dalam bentuk sosialisasi tentang regulasi yang menjadi acuan maka pengelola kegiatan maupun pengurus aset desa mengupayakan dengan mengikuti panduan/modul yang mereka peroleh saat mengikuti pelatihan tentang pengelolaan dana desa disamping itu saat pengadaan barang TPK selalu berkoordinasi dengan pendamping. Begitu juga dalam penatausahaan, pengurus aset desa sudah berupaya dengan mencatat inventaris desa walaupun belum semua. Dari pihak PMD dan Inspektorat Kota Kotamobagu karena belum diterapkan regulasi pengelolaan aset desa maka sebatas sosialisasi berdasarkan pengalaman saja selain itu menyarankan ke pemerintah desa mengikuti aturan pengelolaan Barang Milik Daerah sebagaimana juga yang digunakan oleh mereka dalam pemeriksaan.

Rohim (2009:113) menyatakan salah satu fungsi komunikasi dalam perusahaan adalah fungsi regulatif yang berkaitan dengan peraturan-peraturan yang berlaku dalam suatu perusahaan. Menurut Fiske (1990:7), komunikasi adalah salah satu aktivitas manusia yang diakui setiap orang, namun hanya sedikit yang bisa mendefinisikannya secara memuaskan. Meskipun kita sadar bahwa komunikasi itu penting, namun banyak pihak baik individu maupun institusi yang tidak mampu melakukan definisi atas fungsi komunikasinya. Pemerintah Indonesia sebagai suatu sistem kelembagaan bisa juga dikatakan mengalami hal yang sama. Agar pelaksanaan implementasi kebijakan pengelolaan aset desa berjalan seperti yang diinginkan hendaknya pemerintah Kota Kotamobagu segera melaksanakan salah satu fungsi komunikasi yaitu fungsi regulatif secara berkesinambungan agar semua pihak yang terkait dalam pengelolaan aset desa mendapatkan kepastian peraturan tentang pekerjaan yang boleh dan tidak boleh dilakukan.

3. Selanjutnya terkait aset desa yang tidak memiliki kepastian hukum kepemilikan aset maka upaya yang dilakukan dengan melaporkan ke pemerintah Kota Kotamobagu dan diarahkan semua aset desa yang belum bersertifikat diikut sertakan pada program PTS (Pendaftaran Teknik Sistematis) atau yang lebih dikenal program PRONA (Proyek Operasi Nasional Agraria). Dengan adanya program PRONA yang merupakan kebijakan dari Badan Pertanahan Nasional yang meliputi proses pendaftaran secara masal, pengukuran tanah serta penerbitan sertifikat tanah secara gratis tanpa 
dipungut biaya diharapkan kedepannya semua aset desa sudah memiliki sertifikat agar proses penatausahaan aset desa bisa lebih baik.

Menurut Surjadi (2012:7), pelayanan publik adalah upaya negara untuk memenuhi kebutuhan dasar dan hak-hak sipil setiap warga negara atas barang, jasa dan pelayanan administrasi yang disediakan oleh penyelenggara pelayanan publik. Hakikat pelayanan publik adalah pemberian pelayanan prima kepada masyarakat yang merupakan perwujudan kewajiban aparatur pemerintah sebagai abdi masyarakat. Pendapat lain Moenir (2006:47), pelayanan publik adalah kegiatan yang dilakukan oleh seseorang atau sekelompok orang dengan landasan faktor material melalui sistem, prosedur dan metode tertentu dalam rangka usaha memenuhi kepentingan orang lain sesuai dengan haknya.

4. Belajar dari pengalaman yang sudah terjadi dimana TPK sering kecolongan masalah harga maka upaya yang dilakukan selain menyiasati dari anggaran yang ada, pengelola kegiatan sebelum melakukan penyusunan $\mathrm{RAB}$ sudah memprediksi atau meramal terlebih dahulu kemungkinan kenaikan harga sehingga anggaran yang disusun dihitung lebih untuk kemungkinan kenaikan harga maupun untuk pajak. Peramalan dimaksudkan untuk memperoleh informasi sejauh mana perubahan kenaikan harga pada masa yang akan datang agar pengalaman kecolongan tidak terulang lagi atau bisa diminimalisir.

Menurut Dunn (2000:291), peramalan kebijakan (policy forecasting) merupakan suatu prosedur untuk membuat informasi faktual tentang situasi sosial masa depan atas dasar informasi yang telah ada tentang masalah kebijakan. Adapun tujuan diadakannya peramalan kebijakan untuk memperoleh informasi mengenai perubahan dimasa yang akan datang yang akan mempengaruhi terhadap implementasi kebijakan serta konsekuensinya. Sebelum rekomendasi diformulasikan perlu adanya peramalan kebijakan sehingga akan diperoleh hasil rekomendasi yang benar-benar akurat untuk diberlakukan pada masa yang akan datang.

5. Transparansi merupakan indikator yang sangat penting dalam pembangunan tata pemerintahan yang baik. Selain itu transparansi merupakan salah satu pilihan yang dapat diterapkan dalam mengurangi penyelewengan. Keterlibatan BPD saat musrembang desa sepanjang apa yang sudah ditetapkan dalam APBDes itu yang disetujui BPD, kegiatan yang diminta dalam APBDes masih secara keseluruhan dalam artian pengadaan yang dilakukan belum tentu apakah sesuai dengan yang dibutuhkan desa atau tidak. Terkait hal tersebut maka upaya yang dilakukan BPD dengan menyampaikan permintaan kepada pengurus aset desa dari mulai perencanaan sampai proses kegiatan selesai BPD diberi salinan dengan maksud agar apa-apa yang rencana diadakan, BPD bisa mengetahui apakah pengadaan tersebut betul-betul menjadi kebutuhan desa atau bila ada hal yang mendesak dikarenakan anggaran belum mencukupi diprioritaskan terlebih dahulu. Demikian pula dalam pelaporan pertanggung jawaban pelaksanaan APBDes harus diserahkan juga dalam bentuk tulisan karena dapat digunakan sebagai sarana monitoring dimana salah satu wewenang BPD adalah mengawasi kinerja kepala desa dalam hal ini selaku pengguna anggaran dan pengguna barang. Selain itu dari pihak BPKP Perwakilan Provinsi Sulawesi Utara mengupayakan dengan menyediakan fasilitas yang mempermudah desa dalam pelaporan berupa aplikasi siskeudes.

Menurut UNDP melalui LAN yang dikutip Tangkilisan (2005:115) menyebutkan adanya hubungan sinergis dan kontruktif diantara negara, sektor swasta dan masyarakat disusun 9 pokok karakteristik good governance yang salah satunya adalah transparansi. Transparansi harus dibangun dalam kerangka kebebasan aliran informasi berbagai proses, kelembagaan dan informasi harus dapat diakses secara bebas oleh mereka yang membutuhkannya dan harus dapat disediakan secara memadai dan mudah dimengerti sehingga digunakan sebagai alat monitoring dan evaluasi. Salah satu sarana yang efektif untuk meningkatkan kinerja melalui pengembangan Sistim Informasi Manajemen Aset (SIMA). Melalui SIMA, transparansi kerja dalam pengelolaan aset sangat terjamin tanpa perlu adanya kekhawatiran akan pengawasan dan pengendalian yang lemah.

6. Karena pengelolaan belum maksimal, banyak aset desa yang berpotensi menambah PADes belum pernah memberi kontribusi ke kas desa. Menyikapi hal tersebut maka upaya yang dilakukan pemerintah desa dengan membentuk Badan Usaha Milik Desa (BUMDES). Menurut Pusat Kajian Dinamika Sistem Pembangunan (2007), BUMDES adalah lembaga usaha desa yang dikelola oleh masyarakat dan pemerintah desa dalam upaya memperkuat perekonomian desa dan dibentuk berdasarkan kebutuhan dan potensi desa. Lebih lanjut dinyatakan dalam Undang-Undang bahwa maksud kebutuhan dan potensi desa adalah : 1) kebutuhan masyarakat terutama dalam pemenuhan kebutuhan pokok; 2) tersedia sumber daya desa yang belum dimanfaatkan secara optimal terutama 
kekayaan desa dan terdapat permintaan pasar; 3) tersedia sumber daya manusia yang mampu mengelola badan usaha sebagai aset pengerak perekonomian masyarakat; 4) adanya unit-unit yang merupakan kegiatan ekonomi warga masyarakat yang dikelola secara parsial dan kurang terakomodasi.

\section{Penutup}

Kesimpulan dalam penelitian ini adalah : 1) pada dasarnya setiap ada perencanaan pengadaan kebutuhan desa diawali dengan musrembang yang melibatkan semua lembaga yang ada di desa, proses penatausahaan sesuai arahan dari instansi terkait semua aset harus dicatat dengan baik tetapi kenyataan dilapangan masih dicatat seadanya, pelaporan kepala desa disampaikan secara tertulis kepada Walikota dalam bentuk LPPD dan ke BPD berupa LKPJ, karena kurangnya pengawasan banyak aset yang berpotensi menambah PADes belum dikelola dengan baik; 2) kompetensi SDM yang masih minim, kurangnya komunikasi terkait regulasi, hampir semua aset desa belum diinventarisasi karena belum memiliki kepastian hukum, sikap pelaksana yang belum transparan dalam pelaksanaan tugas dan komitmen organisasi yang belum terbentuk menjadi faktor penghambat pengelolaan aset desa; 3) Pemerintah Kota Kotamobagu mengarahkan semua aset desa yang belum bersertifikat untuk diikut sertakan dalam program PTS. Pemerintah desa dengan BPD mengupayakan agar pengelolaan aset desa lebih baik dengan pembentukan BUMDES.

Saran yang dapat diberikan dalam penelitian ini adalah : 1) lebih fokus pada upaya peningkatan kompetensi pengelola aset desa melalui sosialisasi, bimbingan teknis dan pendidikan pelatihan yang berkesinambungan dengan pemateri yang berkompeten dibidangnya agar kedepan pengelolaan aset desa bisa lebih baik khususnya proses perencanaan, pengadaan, penatausahaan, pelaporan dan pengawasan aset desa; 2) segera melakukan amanat Undang-Undang Desa untuk menginventarisir seluruh aset yang menjadi milik desa karena semua awal penatausahaan aset desa dimulai dari penginventarisasian; 3) segera memberikan pemahaman kepada pengelola aset desa tentang aplikasi Siskeudes sehingga dapat merubah pola pikir mereka bahwa didalam aplikasi tersebut terdapat fitur-fitur tentang aset desa; 4) segera mensosialisasikan sekaligus menerapkan regulasi tentang pengelolaan aset desa kepada seluruh pihak yang berkepentingan agar dalam pelaksanaannya tidak menimbulkan perbedaan pendapat; 5) melegalkan segera aset yang menjadi milik desa dengan cara pembuatan sertifikat dan surat keterangan kepemilikan atas nama desa.

\section{Daftar Pustaka}

BPKP (2015) Petunjuk Pelaksanaan Bimbingan dan Konsultasi Pengelolaan Keuangan Desa. Deputi Bidang Pengawasan Penyelenggaraan Keuangan Daerah.

Dunn, William N. (2000). Pengantar Analisis Kebijakan Publik. Terj. Samodra Wibawa dkk. Yogyakarta : Gadjah Mada University Press.

Edwards, George C. III (1980) Implementing Public Policy. Washington DC: Congresional, Quartely Press.

Endraswara, Suwardi. (2012) Metodologi Penelitian. Yogyakarta :Gadjah Mada University Press.

Fiske, John (1990) Cultural and Communication Studies. Jakarta:Gramedia Pustaka Utama.

Griffin, Ricky W (2004). Manajemen, Edisi 7, Jilid 1, diterjemahkan oleh Gina Gania. Jakarta : Erlangga.

Harian Suara Merdeka.com "Pengelolaan Aset Desa Banyak yang Sindung Riwut”. Solo Metro 12 Mei 2017.

Lestyowati, Jamila (2015) Widyaswara Madya Balai Diklat Keuangan. Yogyakarta. Modul Pengadaan Barang/Jasa di Desa, Haruskah Swakelola.

Lalolo, Liona (2003) Indikator dan Alat Ukur Prinsip Akuntabilitas, Transparansi dan Partisipasi, BAPPENAS, Jakarta.

Mardiasmo (2006) Perwujudan Transparansi dan Akuntabilitas Publik melalui Akuntansi Sektor Publik : Suatu Sarana Good Governance Yogyakarta : UMM-Press.

Martoyo, Susilo (2000). Manajemen Sumber Daya Manusia Edisi 4, Yogyakarta : BPFE.

Moenir, HA. S (2006) Manajemen Pelayanan Umum di Indonesia. Jakarta : Bumi Aksara.

Notoatmodjo, Soekidjo (2009) Pengembangan Sumber Daya Manusia, Jakarta : PT. Rineka Cipta.

Pusat Kajian Dinamika Sistem Pembangunan (PKDSP) Fakultas Ekonomi Universitas Brawijaya. 2007, Buku Panduan Pendirian dan Pengelolaan Badan Usaha Milik Desa (BUMDES), Jakarta : PPRPDN. 
Republik Indonesia. 2016 Peraturan Menteri Dalam Negeri No 1 Tahun 2016 tentang Pengelolaan Aset Desa.

Republik Indonesia. 2014 Undang-Undang No 6 Tahun 2014 tentang Desa.

Risnawati, Dewi (2017) Pengelolaan Aset Desa Dalam Upaya Meningkatkan Kesejahteraan di Desa Krayan Bahagia Kecamatan Long Ikis Kab. Paser. eJournal Ilmu Pemerintahan, Volume 5, No 1, 2017:199-212 Hal. 10.

Rohim, Syaiful (2009). Teori Komunikasi. Jakarta:PT. Rineka Cipta.

Salim H.S (2001) Pengantar Hukum Perdata Tertulis (BW), Sinar Grafika, Yogyakarta.

Satori, Djam'an dan Aan Komariah. (2014). Metodologi Penelitian Kualitatif. Bandung: Cv. Alfabeta.

Sugiyono, (2015) Metode Penelitian Manajemen. Alfabeta Bandung.

Sumini, O.E (2010) Pokok-Pokok Pengelolaan Barang Milik Daerah. Pusdiklat Kekayaan Negara dan Perimbangan Keuangan.

Surjadi (2012) Pengembangan Kinerja Pelayanan Publik. Refika Aditama, Bandung.

Tangkilisan, Hesel Nogi S (2005) Manajemen Publik, Jakarta. Grassindo.

Undang-Undang No. 6 Tahun 2014, tentang Desa.

Wheatley, G.H (1991) Constructivist Perspective on Science and Mathematics Learning. Science Education Journal. 75(1), 9-21.

Zurnali, Cut (2010) Learning Organization, Competency, Orgnizational Commitment and Customer Orientation : Knowledge Worker-Kerangka Riset Manajemen Sumber Daya Manusia Masa Depan. Bandung:Unpad Press 